\title{
Meta-analysis on the association between pathologic complete response and triple-negative breast cancer after neoadjuvant chemotherapy
}

\author{
Kunpeng $\mathrm{Wu}^{1,2 \dagger}$, Qiaozhu Yang ${ }^{3+}$, Yi Liu ${ }^{4}$, Aibing $\mathrm{Wu}^{1 *}$ and Zhixiong Yang ${ }^{1 *}$
}

\begin{abstract}
Background: Triple-negative breast cancer (TNBC) is a special subtype of breast cancer that is characterized by poor prognosis, strong tumor invasion and a high pathologic complete response ( $\mathrm{pCR}$ ) to neoadjuvant chemotherapy (NAC). The pCR rate is a prognostic factor for TNBC. We aimed to evaluate the relationship between $\mathrm{PCR}$ and TNBC after NAC and originally tried to identify factors related to achieving pCR for TNBC using a meta-analysis.

Methods: We systematically searched the literature for pCR and breast cancer after NAC and carefully identified eligibility criteria. The association between $\mathrm{pCR}$ and breast cancer subtypes was estimated using Review Manager, while pCR rates for TNBC and non-TNBC were determined using Meta-Analyst.

Results: This analysis included a total of 9,460 cases from 27 studies. The summary odds ratio estimating the relationship between pCR and breast cancer subtypes (TNBC vs non-TNBC) was 3.02 (95\% confidence interval (Cl), 2.66 to 3.42). The TNBC pCR rate was $28.9 \%(95 \% \mathrm{Cl}, 27.0$ to $30.8 \%$ ) and the non-TNBC was $12.5 \%$ (95\% Cl, 11.7 to $13.4 \%)$. From subgroup analyses, we identified the factors associated with the highest $\mathrm{PCR}$ rates for TNBC.

Conclusions: TNBC has a higher pCR rate than non-TNBC. In the NAC setting, these factors of platinum-containing, more than six cycles, four kinds of drugs, 16 weeks' treatment duration and sequential chemotherapy may contribute to increasing the $\mathrm{PCR}$ rate.
\end{abstract}

Keywords: breast cancer, neoadjuvant chemotherapy, pathologic complete response, meta-analysis

\section{Background}

Triple-negative breast cancer (TNBC) is a subtype of breast cancer that accounts for approximately $15 \%$ of all breast cancers [1,2]. TNBC lacks the three important therapeutic markers for clinical regimens of patients with breast cancer: estrogen receptor (ER), progesterone receptor $(\mathrm{PR})$ and human epidermal growth factor receptor 2 (HER2). Due to the absence of a therapeutic target (endocrine therapy targets the ER and PR, and trastuzumab targets HER2), the prognosis of patients with TNBC is poorer than that of patients with other types of breast cancer. Patients with TNBC are characterized by early recurrence $[3,4]$ and a significantly shorter survival compared with those with nonTNBCs $[5,6]$.

\footnotetext{
*Correspondence: wab801016@163.com; yangzhixiong068@126.com ${ }^{\dagger}$ Equal contributors

${ }^{1}$ Cancer Center, Affiliated Hospital of Guangdong Medical College, 57 Renmin Road, Zhanjiang, PR China

Full list of author information is available at the end of the article
}

Neoadjuvant chemotherapy (NAC) is increasingly being used in the treatment of large operable breast cancers or to prevent lymph node metastases, where it is as effective as adjuvant chemotherapy and considered a standard of treatment for patients with locally advanced breast cancer [7]. The advantages of NAC in operable breast cancer include: increasing the rate of success of breast-conserving surgery by downstaging the primary tumor load, early prevention of cancer metastasis in lymphonodi or viscera and providing suggestions for selecting the adjuvant chemotherapy regimen through estimating the clinical response to NAC and avoiding a potentially ineffective treatment in adjuvant chemotherapy.

Interestingly, several clinical studies on NAC for breast cancers have shown that TNBC has lower survival and higher relapse rates among all breast cancer subsets but has a higher rate of pathologic complete response ( $\mathrm{pCR}$ ) to NAC than other phenotypes and patients with $\mathrm{pCR}$ 
have excellent survival $[1,8]$. In other words, patients with TNBC who do not have pCR are at increased risk of early relapse and death $[1,9]$. pCR has been proven to be a prognostic factor for breast cancer by von Minckwitz and Xiangnan Kong [10,11]. Consequently, pCR plays a very significant role in predicting prognosis and clinical management for patients with TNBC.

We therefore performed a meta-analysis aiming to report the association between NAC and pCR for TNBC. It was also our purpose to observe which factors are potentially related with $\mathrm{pCR}$ in TNBC treated with NAC, such as NAC cycles, drugs and schedules.

\section{Methods}

\section{Literature search}

The MEDLINE, EMBASE and Cochrane Library databases were systematically searched to September 2013. Publications with the following search words in the title, abstract or key words were included: breast cancer, TNBC, NAC, preoperative chemotherapy, pathologic complete response, pathologic complete remission and pathologic response. The studies identified through the search were independently screened by two authors (KW and AW) for inclusion. Any disagreements were arbitrated by a third author (ZY). We did not limit our search by language, country, race or date.

\section{Inclusion and exclusion criteria}

Studies performed using humans regardless of sample size were included if they met the following criteria: papers studying the association between NAC and pCR in TNBCs; all cases definitely diagnosed as breast cancer and where distant metastasis was excluded; ER, PR, HER2 measured by immunohistochemistry (IHC) and/or fluorescence in situ hybridization of primary cancer tissue; pCR explicitly defined; and detailed statistics had to be reported (i.e. patient numbers and percentage of $\mathrm{pCR}$ ). Any investigations that did not meet all inclusion criteria and cross-sectional studies were excluded. If data were duplicated in more than one paper, the most recent paper was included in the analysis.

\section{Data extraction}

Data were independently extracted by two authors (QY and YL) using the same standardized table. The fields extracted included first author, year of publication, NAC schedule (type, number of cycles, interval and treatment duration), and number and percentage of patients achieving $\mathrm{pCR}$ in TNBC and non-TNBC. For articles with the same population resources or overlapping datasets, data were extracted and reported as a single trial.

\section{Statistical analysis}

The Cochrane Collaboration Review Manager 5.1 and Meta-Analyst Beta 3.13 statistical software were used for this meta-analysis. The $\chi^{2}$ and $I^{2}$ test methods were used to evaluate the heterogeneity of the odds ratios (ORs) in the studies. When $I^{2}<50 \%$ and $P>0.05$ for $\chi^{2}$, indicating heterogeneity in the results, the heterogeneity in the studies was considered acceptable and the fixed-effect model with the Mantel-Haenszel method was used for the two-arm meta-analysis or the inverse variance method was used for the single-arm meta-analysis. Otherwise, a random-effect model with the DerSimonian and Laird method was adapted for both the one- and two-arm meta-analyses. Each study was weighted according to the sample size.

Subgroup analyses were executed for NAC cycles, drugs and schedules. The sensitivity was analyzed by excluding small cases studies (defined as $<100$ cases) and changing the effect model to estimate confidence. Potential publication bias was evaluated using funnel plots. An asymmetric plot indicates there was potential publication bias; otherwise, the plot should be shaped like a funnel.

\section{Ethical standards}

This study complies with the current laws of China.

\section{Results}

\section{Eligible studies}

We identified 516 studies in the three databases and their bibliographies of relevant clinical trials. After excluding duplicates $(n=126)$, the titles and abstracts of all remaining studies $(n=390)$ were reviewed. Of these 390 studies, we excluded 353 that did not meet the selection criteria. After reviewing the full text of the remaining 37 studies, we ultimately included 27 studies $[1,8,9,12-35]$ in the final analysis. Ten studies were excluded from the final review for these reasons: insufficient data $(n=1)$ [36], cross-sectional study $(n=1)$ [37], distant metastasis $(n=5)$ [38-42], undefined pCR $(n=1)$

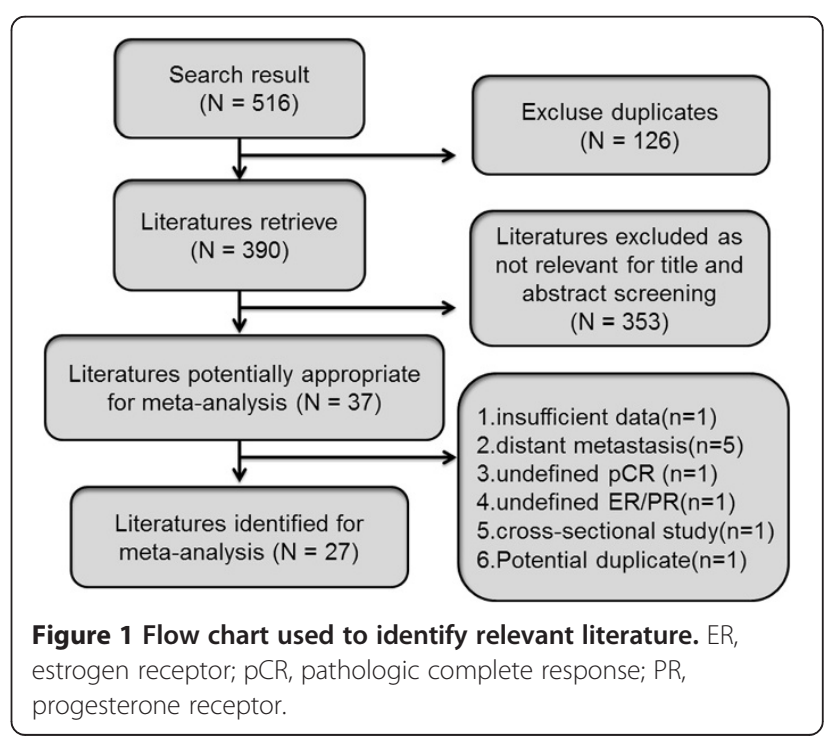


Table 1 Characteristics of the eligible studies

\begin{tabular}{|c|c|c|c|c|c|c|c|c|c|c|}
\hline \multirow[t]{2}{*}{ Author } & \multirow[t]{2}{*}{ Year } & \multirow[t]{2}{*}{ Tumor stage } & \multirow[t]{2}{*}{ Neoadjuvant chemotherapy } & \multicolumn{2}{|c|}{ TNBC } & \multirow{2}{*}{$\begin{array}{l}\text { pCR rate } \\
\text { of TNBC }\end{array}$} & \multicolumn{2}{|c|}{ non-TNBC } & \multirow{2}{*}{$\begin{array}{l}\text { pCR rate of } \\
\text { non-TNBC }\end{array}$} & \multirow[t]{2}{*}{ OR (95\% Cl) } \\
\hline & & & & $\mathrm{pCR}$ & no-pCR & & $\mathrm{pCR}$ & no-pCR & & \\
\hline Rouzier R [8] & 2005 & I, II, III & $\begin{array}{c}12 \text { weeks of P followed by FAC } 4 \text { courses }\left(\text { weekly P }\left(80 \mathrm{mg} / \mathrm{m}^{2}\right) \times\right. \\
\left.12+\mathrm{FAC} \times 4 \text { or } 3 \text { weekly P }\left(225 \mathrm{mg} / \mathrm{m}^{2}\right) \times 4+\mathrm{FAC} \times 4\right)\end{array}$ & 10 & 12 & $45.50 \%$ & 11 & 49 & $18.30 \%$ & $3.71(1.28,10.76)$ \\
\hline Carey LA [1] & 2007 & $\|\| I$, & $\begin{array}{c}\text { A } 60 \mathrm{mg} / \mathrm{m}^{2}+C 600 \mathrm{mg} / \mathrm{m}^{2} \text { every } 2 \text { weeks or } 3 \text { weeks for } 4 \text { cycles, } \\
\text { either alone or as the first component of a sequential AC-taxane } \\
\text { neoadjuvant regimen }\end{array}$ & 9 & 25 & $26.50 \%$ & 8 & 69 & $10.40 \%$ & $3.10(1.08,8.93)$ \\
\hline Goldstein NS [12] & 2007 & $\| A$ to $\| C$ & $\begin{array}{c}\text { FAC every } 3 \text { weeks } \times 6 \text { FEC every } 3 \text { weeks } \times 6 \text { AC every } 2 \text { weeks } \\
\text { (dose dense) } \times 4 \text { then paclitaxel every } 2 \text { weeks (dose dense) } \times 4 \text { AC } \\
\text { every } 3 \text { weeks } \times 4 \text { then P every } 1 \text { week } \times 4\end{array}$ & 12 & 9 & $57.10 \%$ & 16 & 31 & $34.00 \%$ & $2.58(0.90,7.41)$ \\
\hline Keam B [13] & 2007 & $\|\|$, & $\begin{array}{c}\mathrm{D}\left(75 \mathrm{mg} / \mathrm{m}^{2} \text { or } 60 \mathrm{mg} / \mathrm{m}^{2}\right) \text { and } \mathrm{A}\left(60 \mathrm{mg} / \mathrm{m}^{2} \text { or } 50 \mathrm{mg} / \mathrm{m}^{2}\right) \\
\text { by intravenous infusion every } 3 \text { weeks for } 3 \text { cycles }\end{array}$ & 8 & 39 & $17.00 \%$ & 3 & 95 & $3.10 \%$ & $6.50(1.64,25.78)$ \\
\hline Liedtke C [9] & 2008 & I, II, III & $\begin{array}{l}\text { FAC; FEC; weekly or once every } 3 \text { weeks P/D followed by FAC; } \\
\text { weekly or once every } 3 \text { weeks P/D followed by FEC }\end{array}$ & 57 & 198 & $22.40 \%$ & 98 & 765 & $11.40 \%$ & $2.25(1.56,3.23)$ \\
\hline Bidard FC [14] & 2008 & I, II, III & $\begin{array}{c}\mathrm{FEC}\left(\mathrm{F} 500 \mathrm{mg} / \mathrm{m}^{2}, \text { E } 100 \mathrm{mg} / \mathrm{m}^{2}, \text { C } 500 \mathrm{mg} / \mathrm{m}^{2}\right) \text { or FAC } \\
\left(\text { (F } 500 \mathrm{mg} / \mathrm{m}^{2}, \text { A } 60 \mathrm{mg} / \mathrm{m}^{2}, \text { C } 500 \mathrm{mg} / \mathrm{m}^{2}\right) \text {, every } 3 \text { weeks for } 4 \text { to } 6 \text { cycles }\end{array}$ & 21 & 99 & $17.50 \%$ & 7 & 166 & $4.00 \%$ & $5.03(2.06,12.26)$ \\
\hline Julka PK [15] & 2008 & $\| A$ to $\| B$ & $\begin{array}{l}4 \text { cycles ( } 21 \text { days) of Gem } 1,200 \mathrm{mg} / \mathrm{m}^{2}+\mathrm{A} 60 \mathrm{mg} / \mathrm{m}^{2} \\
4 \text { cycles of Gem } 1,000 \mathrm{mg} / \mathrm{m}^{2} \text { plus Cis } 70 \mathrm{mg} / \mathrm{m}^{2}\end{array}$ & 7 & 7 & $50.00 \%$ & 6 & 16 & $27.30 \%$ & $2.67(0.65,10.88)$ \\
\hline Sánchez-Muñoz A [16] & 2008 & $\|\|$, & $\begin{array}{c}\text { Schedule A: E } 90 \mathrm{mg} / \mathrm{m}^{2}+\mathrm{C} 600 \mathrm{mg} / \mathrm{m}^{2} \mathrm{~d} 1 \text { for } 3 \text { cycles followed } \\
\text { by a second sequence with P } 150 \mathrm{mg} / \mathrm{m}^{2}+\text { Gem } 2,500 \mathrm{mg} / \mathrm{m}^{2} \\
\text { d1 } \pm \text { trastuzumab } 2 \mathrm{mg} / \mathrm{kg} / \text { week according to HER2 status } \\
\text { Schedule B: A } 40 \mathrm{mg} / \mathrm{m}^{2} \mathrm{~d} 1+\mathrm{P} 150 \mathrm{mg} / \mathrm{m}^{2}+\text { Gem }\left(2,000 \mathrm{mg} / \mathrm{m}^{2}\right) \\
\text { d2, } 2 \text { weekly for } 6 \text { cycles }\end{array}$ & 14 & 10 & $58.30 \%$ & 17 & 58 & $22.70 \%$ & $4.78(1.80,12.66)$ \\
\hline Sirohi B [17] & 2008 & Mo & $\begin{array}{c}\text { F } 200 \mathrm{mg} / \mathrm{m}^{2} \text { daily with } \mathrm{E} 60 \mathrm{mg} / \mathrm{m}^{2} \text { and Cis } 60 \mathrm{mg} / \mathrm{m}^{2} \\
\text { both repeating } 3 \text { weekly for } 6 \text { courses }\end{array}$ & 1 & 5 & $16.70 \%$ & 5 & 49 & $9.30 \%$ & $1.96(0.19,20.26)$ \\
\hline Darb-Esfahani S [18] & 2009 & $\begin{array}{l}\text { T2 to } 3 \\
\text { No to } 2, \mathrm{MO}\end{array}$ & $\begin{array}{c}\text { A } 50 \mathrm{mg} / \mathrm{m}^{2}+\mathrm{D} 75 \mathrm{mg} / \mathrm{m}^{2} \text { every } 14 \text { days for } 4 \text { cycles or } 4 \text { cycles } \\
\text { A } 60 \mathrm{mg} / \mathrm{m}^{2} \text { plus C } 600 \mathrm{mg} / \mathrm{m}^{2} \text { every } 21 \text { days followed } \\
\text { by D } 100 \mathrm{mg} / \mathrm{m}^{2} \text { every } 21 \text { days for } 4 \text { cycles }\end{array}$ & 8 & 25 & $24.20 \%$ & 5 & 78 & $6.00 \%$ & $4.99(1.50,16.65)$ \\
\hline Sikov WM [19] & 2009 & $\| A$ to $\| B$ & $\begin{array}{l}\mathrm{Cb}(\mathrm{AUG}=6) \text { every } 4 \text { weeks and } \mathrm{P} 80 \mathrm{mg} / \mathrm{m}^{2} \text { weekly for } \\
16 \text { weeks, and weekly trastuzumab was added for HER2 }(+) \text { status }\end{array}$ & 8 & 4 & $66.70 \%$ & 16 & 25 & $39.00 \%$ & $3.13(0.81,12.11)$ \\
\hline Bhargava R [20] & 2010 & I, II, III & $\begin{array}{l}\text { Anthracycline-based therapy: AC, FEC; taxane-based therapy: } \\
\text { T/P + Cb. In many cases a sequential combination of } \\
\text { anthracycline and taxane was given: AC-T. The total number } \\
\text { of cycles ranged from } 4 \text { to } 10 \text { with an average of } 6\end{array}$ & 24 & 55 & $30.40 \%$ & 24 & 256 & $8.60 \%$ & $4.65(2.46,8.80)$ \\
\hline Chang HR [21] & 2010 & $\|\| I$, & $\begin{array}{l}D\left(75 \mathrm{mg} / \mathrm{m}^{2}\right) \text { and } \mathrm{Cb}(\mathrm{AUC}=6) \text { were administered every } 3 \\
\text { weeks for } 4 \text { cycles. Patients with HER2 }(+) \text { tumors were randomized to }\end{array}$ & 6 & 5 & $54.50 \%$ & 13 & 47 & $21.70 \%$ & $4.34(1.14,16.51)$ \\
\hline
\end{tabular}

weeks for 4 cycles. Patients with HER2(+) tumors were randomized to receive either additional weekly trastuzumab preoperatively or TC alone 
Table 1 Characteristics of the eligible studies (Continued)

\begin{tabular}{|c|c|c|c|c|c|c|c|c|c|c|}
\hline Chavez-Macgregor M [22] & 2010 & MO & $\begin{array}{l}\text { Taxane administered: P } 175 \text { to } 250 \mathrm{mg} / \mathrm{m}^{2} \text { on d1, } 3 \text { weekly for } \\
4 \text { cycles; P } 80 \mathrm{mg} / \mathrm{m}^{2} \text { weekly for } 12 \text { doses; or D } 100 \mathrm{mg} / \mathrm{m}^{2} \text { on d } 1 \text {, } \\
3 \text { weekly for } 4 \text { cycles Anthracycline regimens ( } 3 \text { to } 6 \text { cycles): } \\
\text { F } 500 \mathrm{mg} / \mathrm{m}^{2} \text {, E } 100 \mathrm{mg} / \mathrm{m}^{2} \text { and C } 500 \mathrm{mg} / \mathrm{m}^{2} \text { on d1, } \\
\text { d3 weekly; F } 500 \mathrm{mg} / \mathrm{m}^{2} \text { on d1, d4, E } 75 \mathrm{mg} / \mathrm{m}^{2} \text { and } \\
\text { C } 500 \mathrm{mg} / \mathrm{m}^{2} \text { on } \mathrm{d} 1,3 \text { weekly }\end{array}$ & 95 & 395 & $19.40 \%$ & 165 & 1419 & $10.40 \%$ & $2.07(1.57,2.73)$ \\
\hline Chen XS [23] & 2010 & $\begin{array}{l}\text { T3 to } 4 \\
\text { any } \mathrm{N}, \mathrm{MO} ; \mathrm{any} \mathrm{T} \\
\mathrm{N} 2 \text { to } 3, \mathrm{MO}\end{array}$ & $\begin{array}{l}\text { VE: V } 25 \mathrm{mg} / \mathrm{m}^{2} \mathrm{~d} 1, \mathrm{~d} 8+\mathrm{E} 60 \mathrm{mg} / \mathrm{m}^{2} \mathrm{~d} 1, \mathrm{~d} 3 \text { weekly; PCb: } \\
\text { P } 80 \mathrm{mg} / \mathrm{m}^{2}+\mathrm{Cb} \text { AUC }=2 \mathrm{~d} 1, \mathrm{~d} 8, \mathrm{~d} 15,4 \text { weekly; CEF: } \\
\text { C } 500 \mathrm{mg} / \mathrm{m}^{2}, \text { E } 75 \mathrm{mg} / \mathrm{m}^{2} \text { and F } 500 \mathrm{mg} / \mathrm{m}^{2} \mathrm{~d} 1,3 \text { weekly; } \\
\text { CTF: C } 500 \mathrm{mg} / \mathrm{m}^{2}, \text { THP } 50 \mathrm{mg} / \mathrm{m}^{2} \text {, and F } 500 \mathrm{mg} / \mathrm{m}^{2} \mathrm{~d} 1 \\
3 \text { weekly; CEF } \rightarrow \text { T: D } 75 \mathrm{mg} / \mathrm{m}^{2} \text { d1, } 3 \text { weekly; ED: E } \\
\quad 60 \mathrm{mg} / \mathrm{m}^{2}+\text { D } 75 \mathrm{mg} / \mathrm{m}^{2}, 3 \text { weekly }\end{array}$ & 9 & 44 & $17.00 \%$ & 19 & 153 & $11.00 \%$ & $2.07(0.86,4.96)$ \\
\hline Huober J [24] & 2010 & I, II, III & $\begin{array}{c}6 \text { to } 8 \text { cycles of TAC (D } 75 \mathrm{mg} / \mathrm{m}^{2}, \text { A } 50 \mathrm{mg} / \mathrm{m}^{2}, \text { C } 500 \mathrm{mg} / \mathrm{m}^{2} \\
\text { on d1, every } 3 \text { weeks) or } 2 \text { cycles of TAC followed by four } \\
\text { cycles of } V 25 \mathrm{mg} / \mathrm{m} 2 \text { on d1, d8 + capecitabine } 1,000 \mathrm{mg} / \mathrm{m}^{2} \\
\text { orally twice a day on d1 to d14 every } 3 \text { weeks }\end{array}$ & 198 & 311 & $38.90 \%$ & 147 & 820 & $15.20 \%$ & $3.55(2.77,4.56)$ \\
\hline Kim SI [25] & 2010 & MO & $\begin{array}{l}\text { A }\left(50 \mathrm{mg} / \mathrm{m}^{2}, \mathrm{~d} 1\right)+\mathrm{D}\left(75 \mathrm{mg} / \mathrm{m}^{2}, \mathrm{~d} 1\right) \text { chemotherapy } \\
\text { (AT) every } 3 \text { weeks for } 3 \text { cycles }\end{array}$ & 16 & 60 & $21.10 \%$ & 10 & 181 & $5.20 \%$ & $4.83(2.08,11.21)$ \\
\hline Pierga JY [26] & 2010 & $\|\| I$, & $\begin{array}{c}\mathrm{E}\left(75 \mathrm{mg} / \mathrm{m}^{2}\right)+C\left(750 \mathrm{mg} / \mathrm{m}^{2}\right) \text { intravenously every } 3 \text { weeks } \\
\text { for } 4 \text { cycles followed by D }\left(100 \mathrm{mg} / \mathrm{m}^{2}\right) \text { every } 3 \text { weeks for } \\
4 \text { cycles with or without trastuzumab }(8 \mathrm{mg} / \mathrm{kg} \text { at first infusion } \\
\text { then } 6 \mathrm{mg} / \mathrm{kg}) \text { every } 3 \text { weeks }\end{array}$ & 23 & 55 & $29.50 \%$ & 14 & 57 & $19.70 \%$ & $1.70(0.80,3.64)$ \\
\hline Straver ME [27] & 2011 & $\begin{array}{l}\text { T1 to } 3, \\
\text { No to } 2, \mathrm{MO}\end{array}$ & $\begin{array}{c}\text { AC (6 cycles of A } 60 \mathrm{mg} / \mathrm{m}^{2} \text { and C } 600 \mathrm{mg} / \mathrm{m}^{2} \text { every } \\
3 \text { weeks) or AD (6 cycles of A } 50 \mathrm{mg} / \mathrm{m}^{2} \text { and D } 75 \mathrm{mg} / \mathrm{m}^{2} \text {, } \\
\text { every } 3 \text { weeks) }\end{array}$ & 16 & 41 & $28.10 \%$ & 13 & 181 & $6.70 \%$ & $5.43(2.43,12.17)$ \\
\hline Bernsdorf M [28] & 2011 & $\begin{array}{l}\text { T2 to } 3, \\
\text { No to } 3 \mathrm{~b}, \mathrm{M0}\end{array}$ & $\begin{array}{c}\left.4 \text { cycles of EC (E } 90 \mathrm{mg} / \mathrm{m}^{2} \text { and C } 600 \mathrm{mg} / \mathrm{m}^{2}\right) \text { plus } \\
12 \text { weeks of daily treatment with gefitinib } 250 \mathrm{mg} \text { or } \\
\text { EC plus } 12 \text { weeks' treatment with placebo. Chemotherapy } \\
\text { was administered every } 3 \text { weeks }\end{array}$ & 12 & 70 & $14.60 \%$ & 1 & 47 & $2.10 \%$ & $8.06(1.01,64.06)$ \\
\hline Iwata H [29] & 2011 & $\begin{array}{l}\text { T1c to } 3 \\
\text { No, MO; T1 to 3, } \\
\text { N1, MO }\end{array}$ & $\begin{array}{c}4 \text { cycles of } D\left(75 \mathrm{mg} / \mathrm{m}^{2}\right) \text { administered intravenously } \\
\text { every } 21 \text { days followed by } 4 \text { cycles of FEC ( F } 500 \mathrm{mg} / \mathrm{m}^{2} \text {, } \\
\left.\text { E } 100 \mathrm{mg} / \mathrm{m}^{2} \text { and } C 500 \mathrm{mg} / \mathrm{m}^{2}\right) \text { administered intravenously } \\
\text { on } \mathrm{d} 1 \text { every } 21 \text { days before surgery }\end{array}$ & 14 & 15 & $48.30 \%$ & 16 & 84 & $16.00 \%$ & $4.90(1.99,12.09)$ \\
\hline Loo CE [30] & 2011 & $\begin{array}{l}\text { T2 to } 4 \\
\text { N1 to } 3, \mathrm{MO}\end{array}$ & $\begin{array}{c}\text { Either } \mathrm{ER}(+) \text { or }(-) \text {, received } 6 \text { courses of } A C \text {, administered in a } \\
\text { dose-dense schedule (every } 2 \text { weeks). A minority } \\
\text { received } 6 \text { courses of capecitabine }+D \text { or doxorubicin }+D\end{array}$ & 16 & 41 & $28.10 \%$ & 22 & 119 & $15.60 \%$ & $2.11(1.01,4.40)$ \\
\hline Medioni J [31] & 2011 & II, III & $\begin{array}{l}\text { Six 2-weekly courses of Gem } 1,000 \mathrm{mg} / \mathrm{m}^{2}+\mathrm{D} 75 \mathrm{mg} / \mathrm{m}^{2} \\
\text { on d1, d15 and } \mathrm{V} 25 \mathrm{mg} / \mathrm{m}^{2}+\mathrm{E} 100 \mathrm{mg} / \mathrm{m}^{2} \text { on } \mathrm{d} 29, \mathrm{~d} 43 \text {. } \\
\text { Patients with an objective response on d } 56 \text { then received } \\
\text { another cycle of Gem }+\mathrm{D} \text { on } \mathrm{d} 57 \text { and } \mathrm{V}+\mathrm{E} \text { on } \mathrm{d} 71\end{array}$ & 9 & 13 & $40.90 \%$ & 7 & 43 & $14.00 \%$ & $4.25(1.32,13.65)$ \\
\hline
\end{tabular}


Table 1 Characteristics of the eligible studies (Continued)

\begin{tabular}{|c|c|c|c|c|c|c|c|c|c|c|}
\hline Nakahara H [32] & 2011 & T1 to 4 & $\begin{array}{c}\text { HER2(-) tumors started with CE (E } 75 \mathrm{mg} / \mathrm{m} 2 \times \mathrm{d} 1+\mathrm{C} 100 \\
\mathrm{mg} \times \text { daily for } 14 \text { days with } 7 \text { days' rest) for } 4 \text { or } 6 \text { cycles. } \\
\text { HER2(+) tumors initiated with CE (E } 90 \mathrm{mg} / \mathrm{m}^{2} \times \mathrm{d} 1 \text { or } \\
\text { E } 50 \mathrm{mg} / \mathrm{m}^{2} \times \mathrm{d} 1 \text {, d } 8 \text { and } C 100 \mathrm{mg} \times \text { daily for } 14 \text { days } \\
\text { with } 7 \text { days' rest) }\end{array}$ & 5 & 13 & $27.80 \%$ & 3 & 65 & $4.40 \%$ & $8.33(1.77,39.27)$ \\
\hline Wu J [33] & 2011 & $\|, \mid\|$ & $\begin{array}{l}\mathrm{P}\left(175 \mathrm{mg} / \mathrm{m}^{2}\right) \text { or } \mathrm{D}\left(75 \mathrm{mg} / \mathrm{m}^{2}\right)+\text { doxorubicin }\left(60 \mathrm{mg} / \mathrm{m}^{2}\right) \\
\quad \text { or } \mathrm{E}\left(90 \mathrm{mg} / \mathrm{m}^{2}\right) \text { every } 21 \text { days for a total of } 4 \text { cycles }\end{array}$ & 14 & 40 & $25.90 \%$ & 24 & 171 & $12.30 \%$ & $2.49(1.19,5.25)$ \\
\hline Le Tourneau C [34] & 2012 & $\|\| I$, & $\begin{array}{l}4 \text { cycles of intensified FAC (A } 70 \mathrm{mg} / \mathrm{m}^{2} \mathrm{~d} 1, \text { C } 700 \mathrm{mg} / \mathrm{m}^{2} \\
\mathrm{~d} 1+\mathrm{d} 8 \text {, and F } 700 \mathrm{mg} / \mathrm{m}^{2} \mathrm{~d} 1 \text { to } \mathrm{d} 5 \text { ) every } 3 \text { weeks }\end{array}$ & 9 & 10 & $47.40 \%$ & 3 & 30 & $9.10 \%$ & $9.00(2.03,39.93)$ \\
\hline Ono M [35] & 2012 & $\|\| I$, & $\begin{array}{c}\text { Anthracycline-based regimen (AC: A } 60 \mathrm{mg} / \mathrm{m}^{2}+\mathrm{C} 600 \mathrm{mg} / \mathrm{m}^{2} \\
\text { or CEF: C } 600 \mathrm{mg} / \mathrm{m}^{2}+\text { E } 100 \mathrm{mg} / \mathrm{m}^{2}+\mathrm{F} 600 \mathrm{mg} / \mathrm{m}^{2} \text { ) } \\
\text { Taxane-based regimen (weekly P } 80 \mathrm{mg} / \mathrm{m}^{2} \text { or triweekly } \\
\text { D } 75 \mathrm{mg} / \mathrm{m}^{2} \text { ) Anthracycline and taxane sequentially or concurrently } \\
\text { (A } 50 \mathrm{mg} / \mathrm{m}^{2}+\text { D } 60 \mathrm{mg} / \mathrm{m}^{2} \text {, AC or CEF followed by weekly } \\
\text { P or triweekly D) }\end{array}$ & 26 & 66 & $28.30 \%$ & 9 & 70 & $11.40 \%$ & $3.06(1.34,7.02)$ \\
\hline
\end{tabular}

A, adriamycin; C, cyclophosphamide; Cb, carboplatin; Cl, confidence interval; Cis, cisplatin; d, day; D, docetaxel; E, epirubicin; F, 5-fluorouracil; Gem, gemcitabine; HER2, human epidermal growth factor receptor 2; OR, odds ratio; $\mathrm{P}$, paclitaxel; $\mathrm{PCR}$, pathologic complete response; THP, pirarubicin; TNBC, triple-negative breast cancer; $\mathrm{V}$, vinorelbine; $\mathrm{T}$, Taxane/Taxotere; AUC, area under the curve. 
[43] or undefined hormone receptor $(n=1)$ [44]. The same populations were reviewed in two papers [23,45], the data were extracted and reported as a single study. Figure 1 shows a flow diagram with the numbers of relevant studies.

\section{Study characteristics}

In all, 27 studies published between 2005 and 2012 were included in this meta-analysis. Table 1 shows the main characteristics of all of the studies. A total of 9,460 cases from the 27 studies that had pathological results and clinical data were included. Enrollment of participants across the studies was from 1985 to 2009. Most studies enrolled patients who had been diagnosed with breast cancer stages II and III $(n=17)$, but some studies also recruited stage I patients $(n=8)$ and a few studies recruited non-metastatic patients $(n=3)$. According to these studies, the percentage of patients achieving $\mathrm{pCR}$ after NAC was 3.1 to $66.7 \%$ (TNBC, 14.6 to $66.7 \%$; nonTNBC, 3.1 to $39.0 \%$ ). NAC consisted of an anthracycline and/or taxane with other chemotherapeutic regimens.

\section{Pathologic complete response and breast cancer subtypes (triple-negative breast cancer and non-triple- negative breast cancer)}

Figure 2 shows the association between $\mathrm{pCR}$ and breast cancer subtypes (TNBC and non-TNBC) after NAC. In a fixed-effects meta-analysis of all 27 studies, TNBC has a better pCR rate than non-TNBC (the overall summary estimate OR was 3.02; 95\% CI, 2.66 to 3.42) with no obvious evidence of heterogeneity $\left(I^{2}=16 \%, P=0.22\right)$. Figure 3 summarizes the percentage of patients achieving pCR after NAC in TNBC and non-TNBC groups. In a single-group fixed-effects meta-analysis of all 27 studies, the overall summary estimated pCR rate was $28.9 \%$ (95\% CI, 27.0 to $30.8 \%$ ) in TNBC and $12.5 \%$ (95\% CI, 11.7 to $13.4 \%)$ in non-TNBC. There was no obvious evidence of heterogeneity $\left(I^{2}=44.1 \%\right.$ and $I^{2}=43.8 \%$, respectively).

The subgroup analysis outcomes are shown in Table 2. The initially planned subgroup of chemotherapy intermission was not used due to a lack of similar data in these studies. Instead, we used subgroups for NAC treatment duration, which was defined as the period of time that patients were treated with NAC. These subgroup analyses involve treatment cycle $(<4$ cycles, 4 cycles, 6 cycles or $>6$ cycles), types of chemotherapy regimen (anthracycline-based, taxane-containing, platinumcontaining, gemcitabine-containing), the number of chemotherapy drugs (two kinds of drugs, three kinds of drugs or four kinds of drugs), treatment duration ( $<12$ weeks, 12 weeks, 16 weeks or $>16$ weeks) and chemotherapy schedule (conventional vs sequential chemotherapy). We discovered that the $\mathrm{pCR}$ rate was higher with TNBC than with non-TNBC for all subgroups. A singlegroup meta-analysis of all 27 studies [1,8,9,12-35] identified the subgroups (four kinds of chemotherapy drugs, $>6$ cycles, platinum-containing chemotherapy, 16 weeks' treatment duration, sequential chemotherapy) with the highest $\mathrm{pCR}$ rate for both TNBC and non-TNBC patients.

\begin{tabular}{|c|c|c|c|c|c|c|c|c|c|}
\hline Study or Subqroup & \multicolumn{2}{|c|}{ TNBC } & \multicolumn{2}{|c|}{ non-TNBC } & \multicolumn{3}{|c|}{ Odds Ratio } & \multicolumn{2}{|c|}{$\begin{array}{c}\text { Odds Ratio } \\
\text { M-H, Fixed, } 95 \% \mathrm{Cl}\end{array}$} \\
\hline Rouzier R. & 10 & 22 & 11 & 60 & $1.3 \%$ & $3.71[1.28,10.76]$ & 2005 & & \\
\hline Carey L.A. & 9 & 34 & 8 & 77 & $1.4 \%$ & $3.10[1.08,8.93]$ & 2007 & & \\
\hline Keam $B$. & 8 & 47 & 3 & 98 & $0.6 \%$ & $6.50[1.64,25.78]$ & 2007 & & \\
\hline Goldstein N. S. & 12 & 21 & 16 & 47 & $1.7 \%$ & $2.58[0.90,7.41]$ & 2007 & & \\
\hline Bidard F.C. & 21 & 120 & 7 & 173 & $1.9 \%$ & $5.03[2.06,12.26]$ & 2008 & & \\
\hline Sánchez-Muñoz Alfonso & 14 & 24 & 17 & 75 & $1.3 \%$ & $4.78[1.80,12.66]$ & 2008 & & \\
\hline Julka P. K. & 7 & 14 & 6 & 22 & $0.9 \%$ & $2.67[0.65,10.88]$ & 2008 & & \\
\hline Sirohi B. & 1 & 6 & 5 & 54 & $0.3 \%$ & $1.96[0.19,20.26]$ & 2008 & & \\
\hline Liedtke C. & 57 & 255 & 98 & 863 & $13.6 \%$ & $2.25[1.56,3.23]$ & 2008 & & $\rightarrow$ \\
\hline Darb-Esfahani S. & 8 & 33 & 5 & 83 & $0.8 \%$ & $4.99[1.50,16.65]$ & 2008 & & \\
\hline Sikov W.M. & 8 & 12 & 16 & 41 & $0.9 \%$ & $3.13[0.81,12.11]$ & 2009 & & \\
\hline Huober J. & 198 & 509 & 147 & 967 & $24.2 \%$ & $3.55[2.77,4.56]$ & 2010 & & $=$ \\
\hline Bhargava R. & 24 & 79 & 24 & 280 & $2.9 \%$ & $4.65[2.46,8.80]$ & 2010 & & \\
\hline Pierga J.Y. & 23 & 78 & 14 & 71 & $4.0 \%$ & $1.70[0.80,3.64]$ & 2010 & & - \\
\hline Chavez-Macgregor M. & 95 & 490 & 165 & 1584 & $24.6 \%$ & $2.07[1.57,2.73]$ & 2010 & & 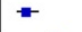 \\
\hline Chang H.R. & 6 & 11 & 13 & 60 & $0.7 \%$ & $4.34[1.14,16.51]$ & 2010 & & \\
\hline Kim S.I. & 16 & 76 & 10 & 191 & $1.8 \%$ & $4.83[2.08,11.21]$ & 2010 & & \\
\hline Chen X.S. & 9 & 44 & 19 & 172 & $2.4 \%$ & $2.07[0.86,4.96]$ & 2010 & & \\
\hline Wu J. & 14 & 54 & 24 & 195 & $3.0 \%$ & $2.49[1.19,5.25]$ & 2011 & & \\
\hline Medioni J. & 9 & 22 & 7 & 50 & $1.0 \%$ & $4.25[1.32,13.65]$ & 2011 & & \\
\hline Straver M.E & 16 & 57 & 13 & 194 & $1.7 \%$ & $5.43[2.43,12.17]$ & 2011 & & \\
\hline I wata $\mathrm{H}$. & 14 & 29 & 16 & 100 & $1.5 \%$ & $4.90[1.99,12.09]$ & 2011 & & \\
\hline LOO C.E. & 16 & 57 & 22 & 141 & $3.6 \%$ & $2.11[1.01,4.40]$ & 2011 & & \\
\hline Nakahara $\mathrm{H}$. & 5 & 18 & 3 & 68 & $0.4 \%$ & $8.33[1.77,39.27]$ & 2011 & & \\
\hline Bernsdorf M. & 12 & 82 & 1 & 48 & $0.4 \%$ & $8.06[1.01,64.06]$ & 2011 & & \\
\hline Le Tourneau C. & 9 & 19 & 3 & 33 & $0.5 \%$ & $9.00[2.03,39.93]$ & 2012 & & \\
\hline Ono $\mathrm{M}$. & 26 & 92 & 9 & 79 & $2.7 \%$ & $3.06[1.34,7.02]$ & 2012 & & \\
\hline Total $(95 \% \mathrm{Cl})$ & & 2305 & & 5826 & $100.0 \%$ & $3.02[2.66,3.42]$ & & & $\downarrow$ \\
\hline Total events & 647 & & 682 & & & & & & \\
\hline $\begin{array}{l}\text { Heterogeneity: } \mathrm{Chi}^{2}=31 \\
\text { Test for overall effect: } \mathrm{Z}=\end{array}$ & $\begin{array}{l}\text { 1, } d f=26 \\
7.18(P<\end{array}$ & $\begin{array}{l}(\mathrm{P}=0.2 \\
0.0000\end{array}$ & $22) ; 1^{2}=1$ & & & & & $\begin{array}{ccc}1 & 1 \\
0.02 & 0.1 & 1 \\
\text { Favours } & \text { non-TNBC }\end{array}$ & Favours \\
\hline
\end{tabular}

Figure 2 Forest plot of odds ratio for achieving pCR after NAC between TNBC and non-TNBC. Cl, confidence interval; TNBC, triple-negative breast cancer; M-H, Mantel-Haenszel method. 


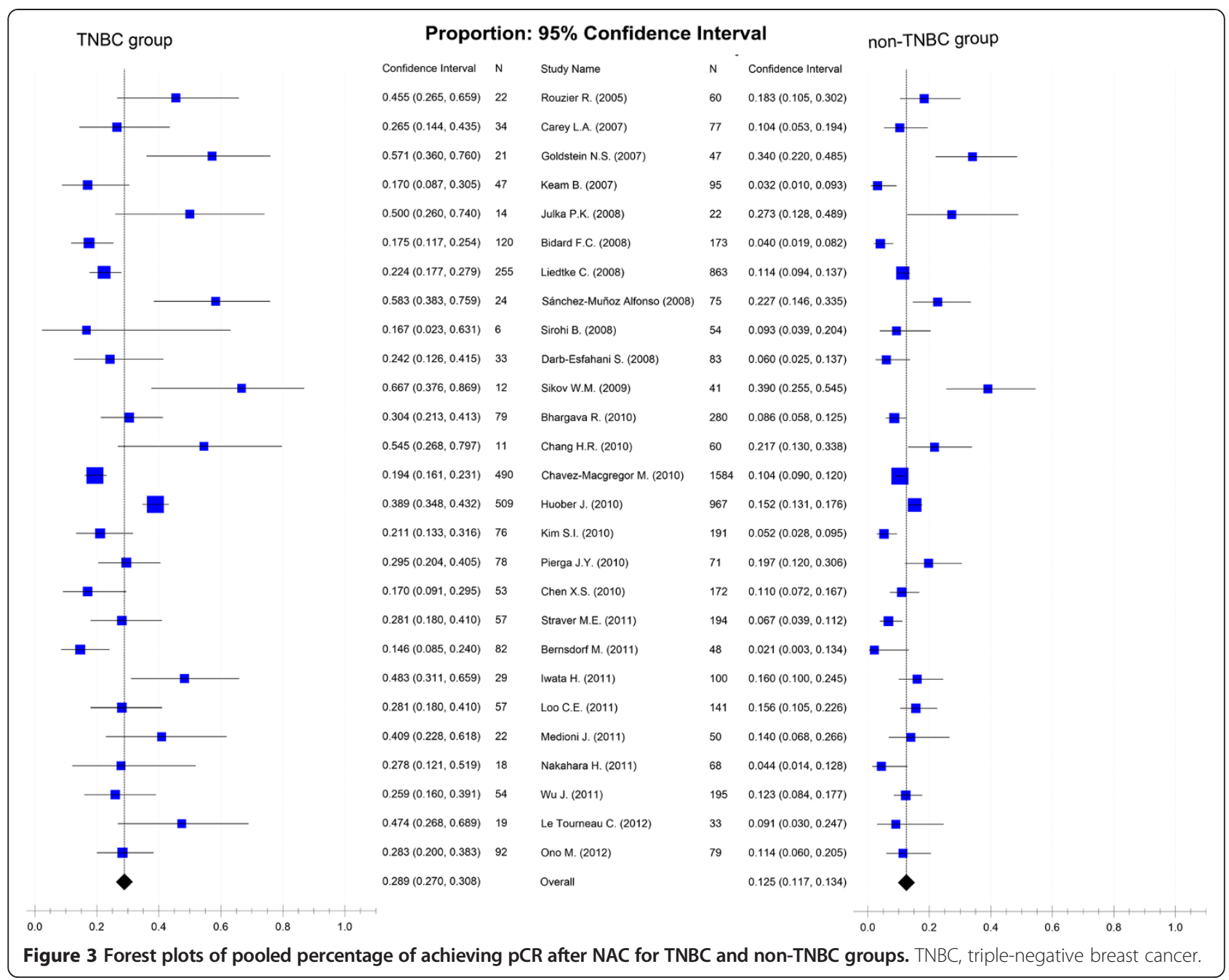

A sensitivity analysis shown that excluding small cases studies and changing the effect model had little effect on estimated $\mathrm{OR}$ and $\mathrm{pCR}$ rate and did not change the strength of the association between NAC and pCR for TNBC and non-TNBC. The ORs were 3.13 (95\% CI, 2.66 to 3.68) for excluding small cases studies and 2.92 ( $95 \%$ CI, 2.56 to 3.34) for changing the effect model. For TNBC patients, the odds of pCR were $27.2 \%$ (95\% CI, 25.3 to $29.2 \%$ ) for excluding small cases studies and $30.5 \%$ (95\% CI, 25.9 to $35.5 \%$ ) for changing the effect model. For non-TNBC patients, the odds of pCR were $11.5 \%$ (95\% CI, 10.7 to $12.5 \%$ ) for excluding small case studies and $12.5 \%$ (95\% CI, 10.4 to $14.9 \%$ ) for changing the effect model. Funnel plots were generated to test for potential publication bias (Figures 4 and 5). Potential publication biases were found in these funnel plots.

\section{Discussion}

TNBC is a subtype of breast cancer that has particular biological features such as high pathologic grade, poor prognosis, short survival, strong tumor invasion, and a high incidence of local relapse and distant metastasis [46]. In addition, a high pCR rate after NAC is also a significant characteristic of TNBC, and $\mathrm{pCR}$ has been proved to be a typical marker predictive of clinical response and survival in TNBC patients [11,47]; however, diverse $\mathrm{pCR}$ rates have been reported in various studies. In this meta-analysis of 27 studies containing 9,460 cases, pCR rates were $28.9 \%$ ( $95 \%$ CI, 27.0 to $30.8 \%$ ) for 2,952 cases of TNBC and 12.5\% (95\% CI, 11.7 to $13.4 \%$ ) for 6,508 cases of non-TNBC. Patients with TNBC have a higher probability of achieving pCR than those with non-TNBC (OR, 3.02; 95\% CI, 2.66 to 3.42 ); that is, the TNBC pCR rate is about two times that of non-TNBC and TNBC exhibits a better response to NAC than nonTNBC.

With the rapid development of molecular and genetic diagnosis techniques, the heterogeneity of breast cancer has been discovered. Based on the analysis of RNA expression profiles, four distinct molecular subtypes of breast cancer (luminal subgroup, basal-like subgroup, HER2 subgroup and normal-like breast tumors) were 
Table 2 Subgroup analyses of various factors related to achieving pathologic complete response

\begin{tabular}{|c|c|c|c|c|c|c|c|}
\hline \multirow[t]{2}{*}{ Category } & \multirow{2}{*}{$\begin{array}{l}\text { Number of studies } \\
\text { (references) }\end{array}$} & \multirow{2}{*}{$\begin{array}{l}\text { Summary estimate } \\
\text { odds ratio }(95 \% \mathrm{Cl})\end{array}$} & \multirow{2}{*}{$\begin{array}{l}\text { Heterogeneity, } \\
I^{2}(\%)\end{array}$} & \multicolumn{4}{|c|}{$\mathrm{pCR}$ rate $(95 \% \mathrm{Cl})$} \\
\hline & & & & $\begin{array}{c}\text { TNBC } \\
(\%)\end{array}$ & $\begin{array}{l}\text { Heterogeneity, } \\
I^{2}(\%)\end{array}$ & $\begin{array}{c}\text { non-TNBC } \\
\text { (\%) }\end{array}$ & $\begin{array}{c}\text { Heterogeneity, } \\
I^{2}(\%)\end{array}$ \\
\hline \multicolumn{8}{|l|}{ Cycles of NAC } \\
\hline$<4$ cycles & $2[13,25]$ & $5.27(2.57,10.79)$ & 0 & $19.6(13.5,27.6)$ & 0 & $4.6(2.7,7.8)$ & 0 \\
\hline 4 cycles & $\begin{array}{c}6[15,21,28, \\
33,34,45]\end{array}$ & $3.51(2.21,5.57)$ & 0 & $29.2(23.0,26.3)$ & 41.4 & $15.0(11.8,18.8)$ & 35.1 \\
\hline 6 cycles & $3[17,27,30]$ & $3.10(1.84,5.22)$ & 35 & $27.6(20.3,36.3)$ & 0 & $11.0(8.2,14.7)$ & 41.3 \\
\hline$>6$ cycles & $3[8,26,29]$ & $2.77(1.66,4.61)$ & 41 & $36.8(28.8,45.6)$ & 33.8 & $17.8(13.4,23.3)$ & 0 \\
\hline \multicolumn{8}{|l|}{ Types of NAC regimen } \\
\hline Anthracycline-based & $\begin{array}{l}19[1,8,9,12-14, \\
16-18,25-34]\end{array}$ & $3.19(2.63,3.88)$ & 7 & $26.8(24.1,29.6)$ & 39.8 & $12.1(10.8,13.5)$ & 43.2 \\
\hline Taxane-containing & $\begin{array}{c}10[8,13,18,19,21,25 \\
26,29,33,45]\end{array}$ & $3.29(2.41,4.48)$ & 0 & $30.5(25.9,35.5)$ & 38.2 & $14.9(12.6,17.5)$ & 44.8 \\
\hline Platinum-containing & $4[17,19,21,45]$ & $3.10(1.59,6.03)$ & 0 & $44.2(30.8,58.5)$ & 31.1 & $21.3(16.3,27.3)$ & 43.6 \\
\hline Gemcitabine-containing & $2[15,31]$ & $3.49(1.42,8.57)$ & 0 & $44.5(29.3,60.8)$ & 0 & $18.8(11.2,29.8)$ & 30.2 \\
\hline \multicolumn{8}{|l|}{ The number of drug in NAC } \\
\hline Two kinds of drugs & $\begin{array}{c}9[13,15,19,21,25, \\
27,32,33,45]\end{array}$ & $3.89(2.75,5.49)$ & 0 & $28.7(23.8,34.2)$ & 36.3 & $12.9(10.7,15.5)$ & 46.1 \\
\hline Three kinds of drugs & $4[14,17,26,34]$ & $2.39(1.77,3.23)$ & 16 & $22.5(18.8,26.5)$ & 19.8 & $11.2(9.5,13.3)$ & 43.6 \\
\hline Four kinds of drugs & $4[8,9,29,31]$ & $4.83(2.80,8.35)$ & 0 & $45.7(35.8,55.9)$ & 0 & $15.5(11.4,20.6)$ & 0 \\
\hline \multicolumn{8}{|c|}{ Total treatment duration of NAC } \\
\hline$<12$ weeks & $2[13,25]$ & $5.27(2.57,10.79)$ & 0 & $19.6(13.5,27.6)$ & 35.4 & $4.6(2.7,7.8)$ & 0 \\
\hline 12 weeks & $\begin{array}{c}7[14,15,21,28 \\
30,33,34]\end{array}$ & $3.42(2.34,4.99)$ & 0 & $24.9(20.5,29.9)$ & 42 & $13.3(10.7,16.3)$ & 42.6 \\
\hline 16 weeks & $2[19,45]$ & $2.88(1.27,6.56)$ & 0 & $44.2(28.4,61.3)$ & 41.4 & $24.8(17.7,33.7)$ & 46.7 \\
\hline$>16$ weeks & $\begin{array}{c}6[8,17,24,26, \\
27,29]\end{array}$ & $3.47(2.80,4.30)$ & 7 & $37.6(34.0,41.2)$ & 25.8 & $14.7(12.9,16.6)$ & 38 \\
\hline \multicolumn{8}{|l|}{ NAC schedules } \\
\hline Conventional chemotherapy & $\begin{array}{c}8[13-15,17,21 \\
25,27,45]\end{array}$ & $4.40(3.02,6.42)$ & 0 & $24.1(19.8,29.0)$ & 35.6 & $9.7(7.7,12.1)$ & 44.5 \\
\hline Sequential chemotherapy & $4[8,26,29,31]$ & $2.96(1.85,4.72)$ & 20 & $37.4(30.0,45.5)$ & 22.5 & $17.2(13.2,22.1)$ & 0 \\
\hline
\end{tabular}

$\mathrm{Cl}$, confidence interval; NAC, neoadjuvant chemotherapy; $\mathrm{PCR}$, pathologic complete response; TNBC, triple-negative breast cancer.

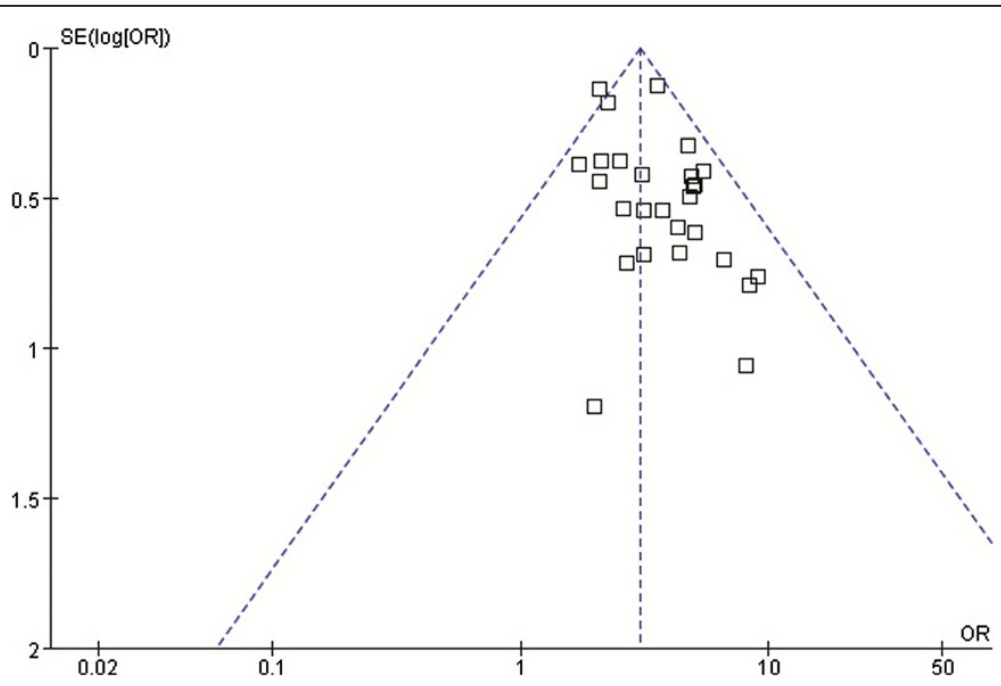

Figure 4 Funnel plot for identifying publication bias in the relationship for achieving pCR between TNBC and non-TNBC. OR, odds ratio. 


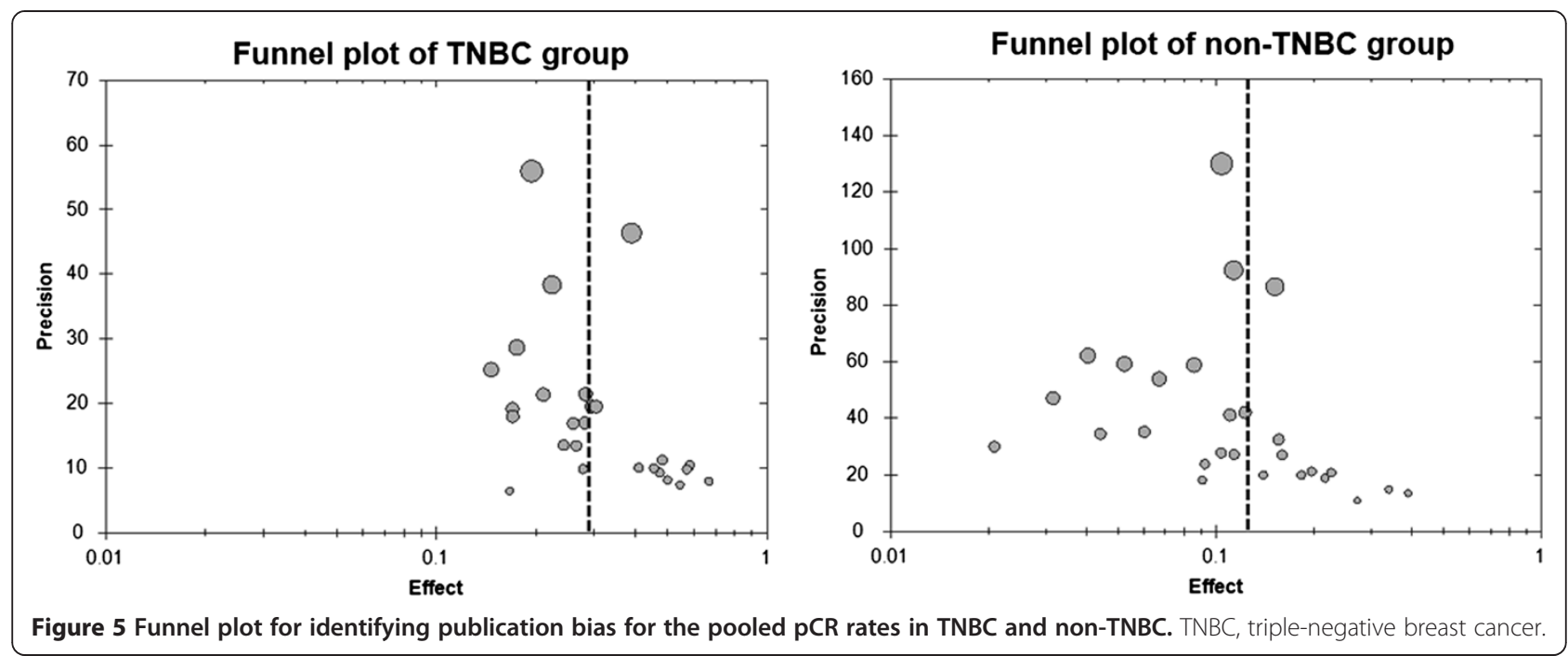

identified and reported by Perou et al. [48]. The basallike breast cancer is IHC characterized by overexpression of cytokeratin 5/6/14 and epidermal growth factor receptor and lack of expression of ER, PR and HER2 $[49,50]$. There is intrinsic homology but incomplete overlap between IHC-defined TNBC and moleculardefined basal-like breast cancer. Nearly $80 \%$ of TNBC cases have a basal-like molecular profile [51,52]. In addition to the basal-like profile, TNBC encompasses other molecular subtypes, particularly normal-like and claudin-low [53]. In this meta-analysis, we found four studies of participants with basal-like breast cancer and an estimated pCR rate of $42.5 \%$ (95\% CI, 32.4 to $53.2 \%$ ). There was no obvious evidence of heterogeneity $\left(I^{2}=\right.$ $31.2 \%)$. Basal-like breast cancer has a higher $\mathrm{pCR}$ rate than TNBC. Thus, there is evidence that the subtype of triple-negative cancers is heterogeneous and we cannot simply consider them a single group.

Both anthracyclines and taxanes are usually used in the neoadjuvant treatment of breast cancer, and patients respond well to them. Of the 27 studies in this meta-analysis, 19 used anthracycline-based NAC and 11 used taxanecontaining regimens. The pCR rates for TNBC were $26.8 \%$ (95\% CI, 24.1 to $29.6 \%$ ) for the anthracycline-based group and $30.5 \%$ (95\% CI, 25.9 to $35.5 \%)$ for the taxanecontaining group, a non-significant difference. Interestingly, the platinum-containing group had a higher $\mathrm{pCR}$ rate than either the anthracycline-based or taxane-containing groups. It is believed that most TNBC cells are expected to have a $B R C A 1$ mutation or absence [54,55], which is useful for the treatment of TNBC since loss of BRCA1 function in TNBC is related to the sensitivity of DNA-damaging chemotherapy agents (platinum, alkylating agents, etc.) and may also be related to the resistance of spindle poisons (taxanes and vinblastines) [56]. TNBC is strongly related to germ-line mutations in the BRCA1 gene, and $90 \%$ of BRCA1-mutated cancers are TNBC [57]. Some researchers have demonstrated that the addition of platinum agents to anthracycline and/or taxane regimens in NAC has promise for outcomes [58]. Although the gemcitabine-containing group included two studies with 108 cases [15,31], we should not ignore this group, which achieved the highest $\mathrm{pCR}$ rate. Due to lack of sufficient cases to support gemcitabine use in NAC for TNBC, more clinical trials should be implemented.

A hypothesis-generating study indicated that TNBC/ basal-like breast cancer had a poorer response to anthracycline-based therapy compared with other breast cancer subtypes [59]. The results of this study were laterally validated through this meta-analysis, which indicated that the anthracycline-based group had the lowest pCR. Although some new drugs have been used in NAC for TNBC (such as EGFR inhibitors (NCT00491816), epothilones (NCT01097642) and ixabepilone (NCT01097642)), the platinum-containing strategy was still the first choice in most clinical trials of TNBC and NAC (NCT00887575, NCT01194869 and NCT00813956). It is a pity that the final reports of these clinical trials have not been submitted; however, these reports were very valuable for providing informative references for the clinical practice. Based on the platinum-containing subgroup analysis of 292 cases from 4 studies [17,19,21,45] and some cell biology research [54-57], we recommend the platinum-containing strategy should be used in NAC for TNBC.

From the subgroup analyses of cycles, drug types, treatment duration and chemotherapy schedules (Table 2), we observed that groups of more than six cycles, four kinds of drugs, 16 weeks treatment duration and sequential chemotherapy obtained the highest $\mathrm{pCR}$ rate in the respective subgroups for TNBC (36.8\%: 95\% CI, 28.8 to 45.6\%; $45.7 \%$ : $95 \%$ CI, 35.8 to 55.9\%; 37.6\%: $95 \%$ CI, 34.0 to $41.2 \%$; $37.4 \%: 95 \% \mathrm{CI}, 30.0$ to $45.5 \%$, respectively). We 
found that the NAC scheme of FAC/TEC-T or T-FAC/ TEC had greater weight in the subgroups for four kinds of drugs $[8,9,29]$ and sequential chemotherapy for TNBC $[8,26,29]$ (the weight was $76.6 \%$ and $84.5 \%$, respectively). This chemotherapy scheme may be a good choice of NAC for TNBC.

Three meta-analyses were published recently on breast cancer and pCR. Von Minckwitz et al. [11] presented a meta-analysis of 6,377 operable and non-metastatic breast cancer patients, who received neoadjuvant anthracyclines or taxanes. They discerned various definitions of $\mathrm{pCR}$ and evaluated the prognostic impact of $\mathrm{pCR}$ on disease-free survival and overall survival in various breast cancer subgroups. The authors concluded that pCR should be conservatively defined as ypT0 ypN0 excluding ductal carcinoma in situ and that pCR is an effective mark of survival for TNBC, luminal B and nonluminal (HER2-positive). Kong et al. [10] completed a meta-analysis that included 16 studies with 3,776 patients with breast cancer to determine whether pathologic response after NAC predicts outcomes. The authors concluded that the pathologic response is prognostic for relapse-free survival, disease-free survival and overall survival. Houssami et al. [60] reported a meta-analysis with two analysis models to provide evidence of the association between various factors for breast cancer and the rates of achieving pCR. Our meta-analysis included 27 studies with 9,460 non-metastatic breast cancer patients, and we aimed to evaluate the association between $\mathrm{pCR}$ and breast cancer subtypes (TNBC and non-TNBC) after NAC, and originally tried to identify factors related to achieving $\mathrm{pCR}$ for TNBC.

There are some potential limitations in this metaanalysis. Hormone receptor assessment varies across different studies, and different IHC standards are used to define positivity. Most studies define ER/PR-negative IHC using the threshold of $<10 \%$ immunoreactive cells. The American Society of Clinical Oncology and the College of American Pathologists guidelines for IHC dictate that a threshold of $<1 \%$ of cells should be used to define ER/PR-negative so that more patients with breast cancer will receive endocrine therapy [53,61]. Moreover, it is unfortunate that sufficient detailed survival data for performing survival analysis are lacking.

\section{Conclusions}

In summary, this meta-analysis provides strong evidence that TNBC has a higher $\mathrm{pCR}$ rate than non-TNBC. In the NAC setting, these factors of platinum-containing, more than six cycles, four kinds of drugs, 16 weeks' treatment duration and sequential chemotherapy may result in a higher $\mathrm{pCR}$ rate. This information provides valuable direction for clinicians performing relevant clinical studies in the future.

\section{Abbreviations}

Cl: confidence interval; ER: estrogen receptor; HER2: human epidermal growth factor receptor 2; IHC: immunohistochemistry; NAC: neoadjuvant chemotherapy; OR: odds ratio; pCR: pathologic complete response;

PR: progesterone receptor; TNBC: triple-negative breast cancer.

\section{Competing interests}

No potential competing interests were disclosed.

\section{Authors' contributions}

KW and QY performed statistical analysis and wrote the manuscript; KW, YL, AW and QY performed literature search and stratified the data; AW and ZY provided meaningful discussion key points; KW and AW revised and edited the manuscript. All authors read and approved the final manuscript.

\section{Acknowledgements}

This work was supported by funding from the National Natural Science Foundation of China (81201672).

\section{Author details}

${ }^{1}$ Cancer Center, Affiliated Hospital of Guangdong Medical College, 57 Renmin Road, Zhanjiang, PR China. ${ }^{2}$ Cancer Center, Heyuan People's hospital, Heyuan, PR China. ${ }^{3}$ Department of Gynecology and Obstetrics, Women and Child Care Institute of Heyuan, Heyuan, PR China. ${ }^{4}$ Guangdong Key Laboratory for Research and Development of Natural Drugs, Guangdong Medical College, Zhanjiang, PR China.

Received: 16 February 2014 Accepted: 4 April 2014

Published: 15 April 2014

\section{References}

1. Carey LA, Dees EC, Sawyer L, Gatti L, Moore DT, Collichio F, Ollila DW, Sartor $\mathrm{Cl}$, Graham ML, Perou CM: The triple negative paradox: primary tumor chemosensitivity of breast cancer subtypes. Clin Cancer Res 2007, 13(8):2329-2334.

2. Dent R, Trudeau M, Pritchard KI, Hanna WM, Kahn HK, Sawka CA, Lickley LA, Rawlinson E, Sun P, Narod SA: Triple-negative breast cancer: clinical features and patterns of recurrence. Clin Cancer Res 2007, 13(15 Pt 1):4429-4434.

3. Dent R, Hanna WM, Trudeau M, Rawlinson E, Sun P, Narod SA: Pattern of metastatic spread in triple-negative breast cancer. Breast Cancer Res Treat 2009, 115(2):423-428.

4. Tischkowitz M, Brunet JS, Begin LR, Huntsman DG, Cheang MC, Akslen LA, Nielsen TO, Foulkes WD: Use of immunohistochemical markers can refine prognosis in triple negative breast cancer. BMC Cancer 2007, 7:134.

5. Boyle P: Triple-negative breast cancer: epidemiological considerations and recommendations. Ann Oncol 2012, 23(Suppl 6):vi7-vi12.

6. Harris LN, Broadwater G, Lin NU, Miron A, Schnitt SJ, Cowan D, Lara J, Bleiweiss I, Berry D, Ellis M, Hayes DF, Winer EP, Dressler L: Molecular subtypes of breast cancer in relation to paclitaxel response and outcomes in women with metastatic disease: results from CALGB 9342. Breast Cancer Res 2006, 8(6):R66.

7. Mieog JS, van der Hage JA, van de Velde CJ: Preoperative chemotherapy for women with operable breast cancer. Cochrane Database Syst Rev 2007, 2:CD005002

8. Rouzier R, Perou CM, Symmans WF, Ibrahim N, Cristofanilli M, Anderson K, Hess KR, Stec J, Ayers M, Wagner P, Morandi P, Fan C, Rabiul I, Ross JS, Hortobagyi GN, Pusztai L: Breast cancer molecular subtypes respond differently to preoperative chemotherapy. Clin Cancer Res 2005, 11(16):5678-5685.

9. Liedtke C, Mazouni C, Hess KR, Andre F, Tordai A, Mejia JA, Symmans WF, Gonzalez-Angulo AM, Hennessy B, Green M, Cristofanilli M, Hortobagyi GN, Pusztai L: Response to neoadjuvant therapy and long-term survival in patients with triple-negative breast cancer. J Clin Oncol 2008, 26(8):1275-1281.

10. Kong X, Moran MS, Zhang N, Haffty B, Yang Q: Meta-analysis confirms achieving pathological complete response after neoadjuvant chemotherapy predicts favourable prognosis for breast cancer patients. Eur J Cancer 2011, 47(14):2084-2090.

11. von Minckwitz G, Untch M, Blohmer JU, Costa SD, Eidtmann H, Fasching PA, Gerber B, Eiermann W, Hilfrich J, Huober J, Jackisch C, Kaufmann M, Konecny GE, Denkert C, Nekljudova V, Mehta K, Loibl S: Definition and 
impact of pathologic complete response on prognosis after neoadjuvant chemotherapy in various intrinsic breast cancer subtypes. J Clin Oncol 2012, 30(15):1796-1804.

12. Goldstein NS, Decker D, Severson D, Schell S, Vicini F, Margolis J, Dekhne NS: Molecular classification system identifies invasive breast carcinoma patients who are most likely and those who are least likely to achieve a complete pathologic response after neoadjuvant chemotherapy. Cancer 2007, 110(8):1687-1696.

13. Keam B, Im SA, Kim HJ, Oh DY, Kim JH, Lee SH, Chie EK, Han W, Kim DW, Moon WK, Kim TY, Park IA, Noh DY, Heo DS, Ha SW, Bang YJ: Prognostic impact of clinicopathologic parameters in stage II/III breast cancer treated with neoadjuvant docetaxel and doxorubicin chemotherapy: paradoxical features of the triple negative breast cancer. BMC Cancer 2007, 7:203.

14. Bidard FC, Matthieu MC, Chollet P, Raoefils I, Abrial C, Domont J, Spielmann M, Delaloge S, Andre F, Penault-Llorca F: p53 status and efficacy of primary anthracyclines/alkylating agent-based regimen according to breast cancer molecular classes. Ann Oncol 2008, 19(7):1261-1265.

15. Julka PK, Chacko RT, Nag S, Parshad R, Nair A, Oh DS, Hu Z, Koppiker CB, Nair S, Dawar R, Dhindsa N, Miller ID, Ma D, Lin B, Awasthy B, Perou CM: A phase II study of sequential neoadjuvant gemcitabine plus doxorubicin followed by gemcitabine plus cisplatin in patients with operable breast cancer: prediction of response using molecular profiling. $\mathrm{Br} J$ Cancer 2008, 98(8):1327-1335

16. Sánchez-Muñoz A, García-Tapiador AM, Martínez-Ortega E, Dueñas-García R, Jaén-Morago A, Ortega-Granados AL, Fernández-Navarro M, Torre-Cabrera C, Dueñas B, Rueda Al, Morales F, Ramírez-Torosa C, Martín-Salvago MD, Sánchez-Rovira P: Tumour molecular subtyping according to hormone receptors and HER2 status defines different pathological complete response to neoadjuvant chemotherapy in patients with locally advanced breast cancer. Clin Trans/ Oncol 2008, 10(10):646-653.

17. Sirohi B, Arnedos M, Popat S, Ashley S, Nerurkar A, Walsh G, Johnston S, Smith IE: Platinum-based chemotherapy in triple-negative breast cancer. Ann Oncol 2008, 19(11):1847-1852.

18. Darb-Esfahani S, Loibl S, Muller BM, Roller M, Denkert C, Komor M, Schluns K, Blohmer JU, Budczies J, Gerber B, Noske A, du Bois A, Weichert W, Jackisch C, Dietel M, Richter K, Kaufmann M, von Minckwitz G: Identification of biologybased breast cancer types with distinct predictive and prognostic features: role of steroid hormone and HER2 receptor expression in patients treated with neoadjuvant anthracycline/taxane-based chemotherapy. Breast Cancer Res 2009, 11(5):R69.

19. Sikov WM, Dizon DS, Strenger R, Legare RD, Theall KP, Graves TA, Gass JS, Kennedy TA, Fenton MA: Frequent pathologic complete responses in aggressive stages II to III breast cancers with every-4-week carboplatin and weekly paclitaxel with or without trastuzumab: a Brown University Oncology Group Study. J Clin Oncol 2009, 27(28):4693-4700.

20. Bhargava R, Beriwal S, Dabbs DJ, Ozbek U, Soran A, Johnson RR, Brufsky AM, Lembersky BC, Ahrendt GM: Immunohistochemical surrogate markers of breast cancer molecular classes predicts response to neoadjuvant chemotherapy: a single institutional experience with 359 cases. Cancer 2010, 116(6):1431-1439.

21. Chang HR, Glaspy J, Allison MA, Kass FC, Elashoff R, Chung DU, Gornbein J: Differential response of triple-negative breast cancer to a docetaxel and carboplatin-based neoadjuvant treatment. Cancer 2010, 116(18):4227-4237.

22. Chavez-Macgregor M, Litton J, Chen H, Giordano SH, Hudis CA, Wolff AC, Valero V, Hortobagyi GN, Bondy ML, Gonzalez-Angulo AM: Pathologic complete response in breast cancer patients receiving anthracyclineand taxane-based neoadjuvant chemotherapy: evaluating the effect of race/ethnicity. Cancer 2010, 116(17):4168-4177.

23. Chen XS, Wu JY, Huang O, Chen CM: Molecular subtype can predict the response and outcome of Chinese locally advanced breast cancer patients treated with preoperative therapy. Oncol Rep 2010, 23:1213-1220

24. Huober J, von Minckwitz G, Denkert C, Tesch H, Weiss E, Zahm DM, Belau A, Khandan F, Hauschild M, Thomssen C, Hogel B, Darb-Esfahani S, Mehta K, Loibl S: Effect of neoadjuvant anthracycline-taxane-based chemotherapy in different biological breast cancer phenotypes: overall results from the GeparTrio study. Breast Cancer Res Treat 2010, 124(1):133-140.

25. Kim SI, Sohn J, Koo JS, Park SH, Park HS, Park BW: Molecular subtypes and tumor response to neoadjuvant chemotherapy in patients with locally advanced breast cancer. Oncology 2010, 79(5-6):324-330.
26. Pierga JY, Delaloge S, Espie M, Brain E, Sigal-Zafrani B, Mathieu MC, Bertheau P, Guinebretiere JM, Spielmann M, Savignoni A, Marty M: A multicenter randomized phase II study of sequential epirubicin/cyclophosphamide followed by docetaxel with or without celecoxib or trastuzumab according to HER2 status, as primary chemotherapy for localized invasive breast cancer patients. Breast Cancer Res Treat 2010, 122(2):429-437.

27. Straver ME, Rutgers EJ, Rodenhuis S, Linn SC, Loo CE, Wesseling J, Russell NS, Oldenburg HS, Antonini N, Vrancken Peeters MT: The relevance of breast cancer subtypes in the outcome of neoadjuvant chemotherapy. Ann Surg Oncol 2010, 17(9):2411-2418.

28. Bernsdorf $M$, Ingvar $C$, Jorgensen $L$, Tuxen MK, Jakobsen EH, Saetersdal A, KimperKarl ML, Kroman N, Balslev E, Ejlertsen B: Effect of adding gefitinib to neoadjuvant chemotherapy in estrogen receptor negative early breast cancer in a randomized phase II trial. Breast Cancer Res Treat 2011, 126(2):463-470.

29. Iwata H, Sato N, Masuda N, Nakamura S, Yamamoto N, Kuroi K, Kurosumi M, Tsuda H, Akiyama F, Ohashi Y, Toi M: Docetaxel followed by fluorouracil/ epirubicin/cyclophosphamide as neoadjuvant chemotherapy for patients with primary breast cancer. Jpn J Clin Oncol 2011, 41(7):867-875.

30. Loo CE, Straver ME, Rodenhuis S, Muller SH, Wesseling J, Vrancken Peeters MJ, Gilhuijs KG: Magnetic resonance imaging response monitoring of breast cancer during neoadjuvant chemotherapy: relevance of breast cancer subtype. J Clin Oncol 2011, 29(6):660-666.

31. Medioni J, Huchon C, Le Frere-Belda MA, Hofmann H, Bats AS, Eme D, Andrieu JM, Oudard S, Lecuru F, Levy E: Neoadjuvant dose-dense gemcitabine plus docetaxel and vinorelbine plus epirubicin for operable breast cancer: improved prognosis in triple-negative tumors. Drugs $R D$ 2011, 11(2):147-157.

32. Nakahara $H$, Yasuda $Y$, Machida E, Maeda Y, Furusawa $H$, Komaki $K$, Funagayama M, Nakahara M, Tamura S, Akiyama F: MR and US imaging for breast cancer patients who underwent conservation surgery after neoadjuvant chemotherapy: comparison of triple negative breast cancer and other intrinsic subtypes. Breast Cancer 2011, 18(3):152-160.

33. Wu J, Li S, Jia W, Su F: Response and prognosis of taxanes and anthracyclines neoadjuvant chemotherapy in patients with triple-negative breast cancer. J Cancer Res Clin Oncol 2011, 137(10):1505-1510.

34. Le Tourneau C, Dettwiler $S$, Beuzeboc P, Alran S, Laurence V, Pierga JY, Freneaux P, Sigal-Zafrani B, Dieras V, Vincent-Salomon A: Pathologic response to short intensified taxane-free neoadjuvant chemotherapy in patients with highly proliferative operable breast cancer. Am J Clin Oncol 2012, 35(3):242-246.

35. Ono M, Tsuda H, Shimizu C, Yamamoto S, Shibata T, Yamamoto H, Hirata T, Yonemori K, Ando M, Tamura K, Katsumata N, Kinoshita T, Takiguchi Y, Tanzawa H, Fujiwara Y: Tumor-infiltrating lymphocytes are correlated with response to neoadjuvant chemotherapy in triple-negative breast cancer. Breast Cancer Res Treat 2012, 132(3):793-805.

36. Chavez-Macgregor M, Brown E, Lei X, Litton J, Meric-Bernstram F, Mettendorf E, Hernandez L, Valero V, Hortobagyi GN, Gonzalez-Angulo AM: Bisphosphonates and pathologic complete response to taxane- and anthracycline-based neoadjuvant chemotherapy in patients with breast cancer. Cancer 2012, 118(2):326-332.

37. Silver DP, Richardson AL, Eklund AC, Wang ZC, Szallasi Z, Li Q, Juul N, Leong CO, Calogrias D, Buraimoh A, Fatima A, Gelman RS, Ryan PD, Tung NM, De Nicolo A, Ganesan S, Miron A, Colin C, Sgroi DC, Ellisen LW, Winer EP, Garber JE: Efficacy of neoadjuvant cisplatin in triple-negative breast cancer. J Clin Oncol 2010, 28(7):1145-1153.

38. Koshy N, Quispe D, Shi R, Mansour R, Burton GV: Cisplatin-gemcitabine therapy in metastatic breast cancer: improved outcome in triple negative breast cancer patients compared to non-triple negative patients. Breast 2010, 19(3):246-248.

39. Chan D, Yeo WL, Tiemsim Cordero M, Wong Cl, Chuah B, Soo R, Tan SH Lim SE, Goh BC, Lee SC: Phase II study of gemcitabine and carboplatin in metastatic breast cancers with prior exposure to anthracyclines and taxanes. Investig New Drugs 2010, 28(6):859-865.

40. Fan $Y, X u$ BH, Yuan P, Ma F, Wang JY, Ding XY, Zhang P, Li Q, Cai RG: Docetaxel-cisplatin might be superior to docetaxel-capecitabine in the first-line treatment of metastatic triple-negative breast cancer. Ann Oncol 2013, 24(5):1219-1225.

41. Staudacher L, Cottu PH, Dieras V, Vincent-Salomon A, Guilhaume MN, Escalup L, Dorval T, Beuzeboc P, Mignot L, Pierga JY: Platinum-based chemotherapy in metastatic triple-negative breast cancer: the Institut Curie experience. Ann Oncol 2011, 22(4):848-856. 
42. Uhm JE, Park YH, Yi SY, Cho EY, Choi YL, Lee SJ, Park MJ, Lee SH, Jun HJ, Ahn JS, Kang WK, Park K, Im YH: Treatment outcomes and clinicopathologic characteristics of triple-negative breast cancer patients who received platinum-containing chemotherapy. Int J Cancer 2009, 124(6):1457-1462.

43. Nogi H, Kobayashi T, Suzuki M, Tabei I, Kawase K, Toriumi Y, Fukushima H, Uchida K: EGFR as paradoxical predictor of chemosensitivity and outcome among triple-negative breast cancer. Oncol Rep 2009, 21(2):413-417.

44. Jones RL, Rojo F, A'Hern R, Villena N, Salter J, Corominas JM, Servitja S, Smith IE, Rovira A, Reis-Filho JS, Dowsett M, Albanell J: Nuclear NF-kappaB/ p65 expression and response to neoadjuvant chemotherapy in breast cancer. J Clin Pathol 2011, 64(2):130-135.

45. Chen XS, Nie XQ, Chen CM, Wu JY, WU J, Lu JS, Shao ZM, Shen ZZ, Shen KW: Weekly paclitaxel plus carboplatin is an effective nonanthracyclinecontaining regimen as neoadjuvant chemotherapy for breast cancer. Ann Oncol 2010, 21(5):961-967.

46. Bauer KR, Brown M, Cress RD, Parise CA, Caggiano V: Descriptive analysis of estrogen receptor (ER)-negative, progesterone receptor (PR)-negative, and HER2-negative invasive breast cancer, the so-called triple-negative phenotype: a population-based study from the California cancer registry. Cancer 2007, 109(9):1721-1728.

47. Bayraktar S, Gluck S: Molecularly targeted therapies for metastatic triplenegative breast cancer. Breast Cancer Res Treat 2013, 138(1):21-35.

48. Perou CM, Sorlie T, Eisen MB, van de Rijn M, Jeffrey SS, Rees CA, Pollack JR, Ross DT, Johnsen H, Akslen LA, Fluge O, Pergamenschikov A, Williams C, Zhu SX, Lonning PE, Borresen-Dale AL, Brown PO, Botstein D: Molecular portraits of human breast tumours. Nature 2000, 406(6797):747-752.

49. Metzger-Filho O, Tutt A, de Azambuja E, Saini KS, Viale G, Loi S, Bradbury I, Bliss JM, Azim HA Jr, Ellis P, Di Leo A, Baselga J, Sotiriou C, Piccart-Gebhart M: Dissecting the heterogeneity of triple-negative breast cancer. J Clin Oncol 2012, 30(15):1879-1887.

50. Rakha EA, El-Sayed ME, Green AR, Lee AH, Robertson JF, Ellis IO: Prognostic markers in triple-negative breast cancer. Cancer 2007, 109(1):25-32.

51. Weigelt B, Baehner FL, Reis-Filho JS: The contribution of gene expression profiling to breast cancer classification, prognostication and prediction: a retrospective of the last decade. J Pathol 2010, 220(2):263-280.

52. Cheang MC, Voduc D, Bajdik C, Leung S, McKinney S, Chia SK, Perou CM, Nielsen TO: Basal-like breast cancer defined by five biomarkers has superior prognostic value than triple-negative phenotype. Clin Cancer Res 2008, 14(5):1368-1376.

53. Penault-Llorca F, Viale G: Pathological and molecular diagnosis of triplenegative breast cancer: a clinical perspective. Ann Oncol 2012 23(Suppl 6):vi19-vi22.

54. Comen E, Davids M, Kirchhoff T, Hudis C, Offit K, Robson M: Relative contributions of BRCA1 and BRCA2 mutations to 'triple-negative' breast cancer in Ashkenazi women. Breast Cancer Res Treat 2011, 129(1):185-190.

55. Lee E, McKean-Cowdin R, Ma H, Spicer DV, Van Den Berg D, Bernstein L, Ursin G: Characteristics of triple-negative breast cancer in patients with a BRCA1 mutation: results from a population-based study of young women. J Clin Oncol 2011, 29(33):4373-4380.

56. Kennedy RD, Quinn JE, Mullan PB, Johnston PG, Harkin DP: The role of BRCA1 in the cellular response to chemotherapy. J Natl Cancer Inst 2004, 96(22):1659-1668

57. Foulkes WD, Smith IE, Reis-Filho JS: Triple-negative breast cancer. N Engl J Med 2010, 363(20):1938-1948.

58. Gelmon K, Dent R, Mackey JR, Laing K, McLeod D, Verma S: Targeting triple-negative breast cancer: optimising therapeutic outcomes. Ann Oncol 2012, 23(9):2223-2234.

59. Martin M, Romero A, Cheang MC, Lopez Garcia-Asenjo JA, Garcia-Saenz JA, Oliva B, Roman JM, He X, Casado A, de la Torre J, Furio V, Puente J, Caldés T, Vidart JA, Lopez-Tarruella S, Diaz-Rubio E, Perou CM: Genomic predictors of response to doxorubicin versus docetaxel in primary breast cancer. Breast Cancer Res Treat 2011, 128(1):127-136.

60. Houssami N, Macaskill P, von Minckwitz G, Marinovich ML, Mamounas E: Meta-analysis of the association of breast cancer subtype and pathologic complete response to neoadjuvant chemotherapy. Eur $J$ Cancer 2012, 48(18):3342-3354.
61. Hammond ME, Hayes DF, Dowsett M, Allred DC, Hagerty KL, Badve S, Fitzgibbons PL, Francis G, Goldstein NS, Hayes M, Hicks DG, Lester S, Love R, Mangu PB, McShane L, Miller K, Osborne CK, Paik S, Perlmutter J, Rhodes A, Sasano H, Schwartz JN, Sweep FC, Taube S, Torlakovic EE, Valenstein P, Viale G, Visscher D, Wheeler T, Williams RB, et al: American Society of Clinical Oncology/College of American Pathologists guideline recommendations for immunohistochemical testing of estrogen and progesterone receptors in breast cancer (unabridged version). Arch Pathol Lab Med 2010, 134(7):e48-e72.

doi:10.1186/1477-7819-12-95

Cite this article as: Wu et al.: Meta-analysis on the association between pathologic complete response and triple-negative breast cancer after neoadjuvant chemotherapy. World Journal of Surgical Oncology 2014 12:95.

\section{Submit your next manuscript to BioMed Central and take full advantage of:}

- Convenient online submission

- Thorough peer review

- No space constraints or color figure charges

- Immediate publication on acceptance

- Inclusion in PubMed, CAS, Scopus and Google Scholar

- Research which is freely available for redistribution 